\title{
Grand Theatre, Oratory and Anthropology in the Documentaries of Andrzej Fidyk
}

Images vol. XV/no. 24 Poznań 2014 ISSN 1731-450X

Andrzej Fidyk has made 25 documentaries for Polish and British television. The process of discovery presented in his films can be said to represent an anthropological view of the world. In this sense, he is - as Kapuściński put it - like Herodotus, the first reporter in the annals of the world,[1] who some 2,500 years ago related events from places he had visited. Research on Fidyk's films impels one to apply methods typical of research in anthropology, journalism, film studies, and rhetoric. Fidyk can be considered a film orator, who makes use of a favoured set of themes, motifs, topoi, stylised narrations and stylistic models.

According to Peter Wollen's concept of film orator (1970's), a filmmaker is understood as a secondary construction, a structure in accord with the model of creation typical of the director. This concerns the identification in the film script of the director's style, which is manifest in reoccurring motifs, themes, fundamental conflicts, and stylistic models.[2] For the purposes of this brief study, the orator shall be understood as the film director and the oratory that is subject to analysis - the documentary film. The basic function of oratory can be said to be the communicative turn towards the audience with the aid of a chosen medium - in this particular case, the films by Andrzej Fidyk and their singular documentation of the world.

According to Fidyk, the most important aim of a documentary should be for the film to appeal to the viewer - meaning that his films are bound to be effective and reach the communicative aim set by the director. This process is most visible in documentary film, together with its move in this context to TV, where the documentary became a standard genre in Poland after 1989. The battle over viewers and popularity means that television programmes have to be attractive.

In the case of documentary film, the issue is not the shallowness of this appeal, but rather need for attractive means of presenting important subjects in the social, political and historical sphere. The director had this to say on the above in an interview for Film Quarterly:

[...] the attractiveness of film - that inclines the average person to watch it - is for them (film festival jurors, BFL) - less important. For me therefore

[1] Ryszard Kapuściński recognised Herodotus as the first reporter of his kind in his work Podróże $z$ Herodotem [Travels with Herodotus].
[2] See: G. Joost, Bild-Sprache. Die audio-wisuelle Rhetorik des Films, Transcript, Bielefeld 2008, pp. 5-6. 
in the phrase 'documentary film' the word 'film' is no less important than 'documentary itself'. [3]

In media discourse it is often said that a particular film is a performance with a capital P.[4] Most often, this signifies an action film, made with an emphasis on the richness of its visual components. In this context, mega-productions have pride of place, with the special effects and other tricks of film craft they employ, aimed at making the spectacle as attractive as possible and thereby glue the audience to the screen. This is the very same path that Fidyk takes as a documentalist par excellance, explaining:

I am foremost an artist involved with television, and I am less involved with film. From the very beginning, I understood that even the most important, profound documentary in the world, if it is boring, badly made and the viewer changes channels (meaning the film will not be watched), then this film has no value.[5]

Fidyk's work, however, amounts to more than simply an attractively told story. His films are often a cinematic version of performances, recorded with the aid of a camera placed amid street spectacles, such as parades, carnivals or even striptease performances - all serving as his film set in situ.

Fidyk therefore sees film as a performance - a magnet that attracts the passing glances of the contemporary viewer, who most often has a large television with HD and a satellite dish or cable. This is why the director on almost every occasion creates his work in this particular way for the largest possible impact on the audience. Fidyk admits that:

In every second of work on the film - writing the screenplay, shooting, editing - I have the viewer in mind, put myself in their position. I don't think of myself but only of the audience. My aim is not to give them the opportunity to leave and go to the kitchen for a cup of tea; and that what they see, they remember for their entire life.[6] [...] emotions have always been important for me - my aim has always been that my films were a type of performance.[7]

[3] "Sztuka opowiadania" [The Art of Storytelling], Fidyk in conversation with W. Micher, Kwartalnik Filmowy 1998, no. 23 (jesień) p. 107.

[4] Milton Singer already in the 1970s "began to use the term cultural performance, embracing a wide variety of cultural phenomena such as artistic phenomena in the form of concerts, theatre, as well as ritual performances manifest in collective prayer, ritual recitations and ritual ceremonies" According to Stownik terminów teatralnych [Polish Dictionary of Theatrical Terms - P. Pavis, 2005] "A performance or spectacle is everything that is designated for viewing". It is clear that this definition is unusually broad. Under such a definition, performance "may stand for [...] particular forms of performance arts (dance, opera, film, pantomime, circus etc.), as well as theatre (particularly in respect to its visual sphere). Other modes of action related to viewing and participating also can be considered (sport, cult or ritual ceremonies, public ceremonies etc.). In a word, all manner of cultural performances that fall into the ethnology basket". All the elements therefore that can serve to describe performance, despite their broad variety, nonetheless share a common plane, which is - one needs to underscore - a richness of visual components that leave the audience in thrall (in the act of viewing).

[5] "Sztuka opowiadania"...

[6] Ibidem, p. 118.

[7] Ibidem, p. 116. 
It can therefore be argued that Fidyk creates films of a performance nature, which can be understood in terms of two aspects. First, the director films spectacles per se. Examples are the two North Korean films Defilada [Parade] and Yodok Stories, and the Brazilian film Karnawat, największe party świata [Carnaval. The Biggest Party in the World]; secondly, as creating cinema with a masterly virtuosity. The documentary Defilada came to be thanks to the fact that Fidyk was shooting the ceremonies of the 4oth anniversery of the North Korean Democratic Peoples' Republic, with the permission of his North Korean "guardians". A documentary was completed - according to official propaganda - that praised the rule of Kim Ir Sen. In the wider world beyond North Korea, however, the documentary was living proof of North Korean totalitarian rule. The film to a large extent is made up of spectacles and vibrant images created in honour of the great leader. Examples of such are images of thousands of children and youth parading in ceremonies.

In this context, the Fidyk documentary Yodok Stories presents a group of former inmates of the Yodok concentration camp, whose stories are in part related traditionally and in part, as fragments of a musical. This genre was chosen by the director to tell the world at large of the living hell of the labour camps in North Korea. Karnawat, największe party świata is set across several scenes: the carnival of beauty and debauchery in Rio; the Brazilian Favelas, where the poorest class lives; and the streets of Rio, where everyone steals in order to have enough money for a ticket to the Carnival Hippodrome.

Another Fidyk documentary, Taniec trzcin [Dance of the Sugar Canes], paints a picture deeply set in the tradition of virtuous dances performed by maidens for King Suazi Mswati III on the eve of his betrothel to yet another wife, who is chosen from among the hundreds of women at this ritual. The film is swathed in song and dance, and bathed in the grandeur that surrounds King Suazi Mswati III.

The film Kiniarze z Kalkuty [Calcutta Movie Junkies] can be said to be in the very same spirit of the grand stage, a documentary relating the story of an Indian travelling cinema that organises screenings for locals in various regions. Fidyk's documentary Rosyjski striptiz [The Russian Striptease] is also in the performance vein, with its depiction of Russian post-communism in decline characterised in the act of striptease, where the audience is witness to fantastic orgies with dwarfs and clowns, with children also keeping adult company.

In his early documentaries, such as Maszynista (Train Driver) and Idzie Grześ przez wieś (Robin Brown Strolls Through Town), Fidyk's virtuosity in the art of film can be clearly seen. The protagonist of this documentary, which runs for several minutes, is Brezhnev, who the director films during a ceremony where medals and distinctions are being awarded to delegates from socialist countries. There would not be anything out of the ordinary in such a scenario if not for the fact that the award ceremony is paralleled with scenes of women spending time 
in the sauna to the sound track of a lively song of unfulfilled love. The latter film was Andrzej Fidyk's debut at the Kraków Festival of Documentary Films. The documentary tells the tale of Polish phantom-trains from which cargo vanishes on route from town $A$ to town $B$. As the director explains, these goods are pilfered by railway employees when the trains are in the siding. Because the film maker "never caught anyone" stealing, the situations presented in the film became staged into a theatre performance, while among the "supposed" eye witnesses, the director himself appears.

The grand theatricality of Fidyk's films is also present as a metaphorical vehicle. In this context, one needs to examine the metaphor of theatre, whose provenance dates back to Plato, Montaigne, Erasmus of Rotterdam, Shakespeare, Calderón de la Barca etc. The best known description comes from Shakespeare: "Totus mundus agit histrionem" (All the World's a Stage). Another well-known interpretation of this metaphor is cited from Erasmus of Rotterdam in his work The Prais of Folly, "For what else is the life of man but a kind of play in which men in various costumes perform until the director motions them offstage?" Equally famous is Calderon's phrase in the play Life is a Dream. The playwright notes that the world is a stage and the people on it play their role accordingly. The beginning of this spectacle played by mankind is to be the birth of a person and the end, their death. People are only equal in relation to death.

The director reaches for the metaphor of the world as a theatre in itself, creating the recognisable topos of teatrum mundi in his work.[8] The protagonists in Fidyk's documentaries take up various places on the stage of the world, play various roles that were assigned from birth. In Yodok Stories, for example, they are set in concentration camps for "traitors of the people" and are persecuted. In the film Ostatki, they are singular marionettes in the Palace of Science and Culture at the last congress of the KC PZPR (Central Committee of the Polish United Workers' Party). They are also drunkards in villages in Belarus (Białoruski walc [Belarusian Waltz]), or young Russians who wish to earn a living in a country "of new opportunities" by doing striptease (Rosyjski striptiz).

In the documentary Defilada, for example, the indoctrinated protagonists create a theatrical role as happy citizens of the Korean Democratic People's Republic. Sometimes the actors of a real life spectacle put on masks, so as to chose "another face" for their role - then a beggar plays, for example, king of the carnival (Karnawat, największe party świata). On another occasion, a person-actor dreams their other face when they are part of the audience in a travelling cinema, bringing films from Bollywood (Kiniarze z Kalkuty).

Moreover, the films by this Polish director present the issues of the collective in an intriguing way. His particular interest in distant cultures and their societies means Fidyk takes on the role of an anthro-

[8] A leitmotif that with the growth of literature and its popularity became recognised as a topos. 
pologist, whose documentaries arise thanks to a specific discovery of the "other". The intellectual journeys completed on route to Brazil, Swaziland, India, Belorus, Russia, North Korea and South Korea, Teheran and many other places mean that Fidyk's work can be interpreted as "grand journalism" [9] in exploring the "other world", while the director can be considered as a reporter of "large-scale cinematic documentary", whose genre is based on a passion for discovery and particular precision of form. Exploring the world and sharing these experiences with the audience are reminiscent of a particular journalism, which as far as the written word is concerned, is practiced in Poland among others, by Wojciech Jagielski, a highly valued journalist in the eyes of Fidyk. It ought to be added that in local television journalism a similar role in the media was played by Waldemar Milewicz, who in war dispatches from the cycle Dziwny jest ten świat (What a Strange World) attempted to present the world of autochthons to the audience and bring to light the truth on disagreements and long-term armed conflicts that ravage the world at large.

It may be argued that a given documentary makes use of the filmmaker's experience, their knowledge, as well as the emotions experienced during real events and by those engaged in them. The discovery of a cinematic world - especially one that is distant in terms of culture and society - allows the reporter, and especially the documentary filmmaker, to take on two possible approaches: emic and etic. [10] The former in this context signifies that in documenting this world in their work the author has based this worldview from the inside through their insightful exploration. This could be said to be a participatory record that demands empathy in research and accordingly lends this texture to the reportage, searching for the truth[11] - so-called narrative journalism.

In this respect, the Polish author Kapuścinski states that that this genre of journalism is a means of discovering and relating what really occurs across the world. It is a characteristic means of observation for those who wish to discover the world and its people from within - discovering its reality as a system, which in turn lends itself to documentation thanks to the observer's own participation.

In this light, the concept of emic is a beacon for Fidyk during the collection of materials for the documentary and also functions in

[9] See: K. Kąkolewski, “Reportaż” [Reportage], in: Teoria i praktyka dziennikarstwa. Wybrane zagadnienia, eds. B. Golko, M. Kafel, Z. Mitzner, Państwowe Wydaw. Naukowe, Warszawa 1964.

[10] See: S. Latocha, Poza gatunki. Antropologiczna refleksja nad dziennikarstwem [Beyond Genre. An Anthropological Reflection on Journalism], Acta Universitatis Lodziensis Folia Literaria Polonica 2012, 3 (17), pp. 50-6o. For the first time the author of the article reached beyond genealogy and discussed anthropology and its meaning in terms of discovering the world and the creation of written texts - foremost newspaper ones. It can be maintained that the dual vector form of cognition is also typical of audio-visual texts such as reportage and documentary films. Emic (within) and etic (without) are two means therefore of understanding the world, which initiate two means of organising text.

[11] R. Kapuściński divided journalism into two types: journalism for immediate consumption, informative, news-based; and journalism that documents, searches for the truth. According to Kapuściński, Herodotus practiced the latter. 
the search for credible gophers who act as go-betweens between the world of the subject within and the world without - the world of the observer. Emic is also a means of discovery and documentation tied to deep states of empathy - examples of such being the film Karwanale. In this documentary, the responses of a deaf and dumb poet have been carefully constructed: she is the female narrator belonging to the world presented, who to a significant degree can be considered a porte parole for the director. The poet resonates with the omnipresent and prevailing samba that residents of Rio "are born with", and despite the fact that it was the Carnival that made her deaf, she loves it and all its spectacle. At the same time, the poet perfectly understands people living in the slums, their problems and misery. In Kiniarzy $z$ Kalkuty, expressions of emic can be found in what the cripple Mama has to say - somewhat eccentric in his actions and egocentric drunkenness who notwithstanding, knows almost everything there is about Indian cinema.

In the documentary Tańcu trzcin, an illustration of such an emic character are the confessions of teenage girls who are preparing for the ritual dance before Mswatim III. In the film Yodok Stories, which relates the story of those who fell victim to the North Korean regime, Fidyk used a narrative inversion where those who escaped from North Korea are able to speak out in South Korea - in comfort and without rushing - relating their experiences of the Yodok camps. The process of understanding the system from within, the director's observations through being in situ, in the local community itself, provides an unrepeatable opportunity to document the world from the perspective of a given culture's autochthons. The observer thus has at their disposal instruments such as conducting interviews,[12] filming daily rituals and ritual ceremonies. These are manifests of a cultural system, which in itself represents an integral whole.[13]

Alan Barnard maintains that the emic model of the world does not reflect the local model of the world, does not bring the underlying understanding of the observer and the observed to the same plane, but represents the intellectual construct of the former - one based on local categories.[14] The anthropologist therefore in the process of discovering the 'other' does not put aside their subjectivity; one through which they come to discover and create a picture of the world observed and the people living in it. The view of the world may be given a measure of privilege by the anthropologist - one that leads to an internalisation of the cognitive process that equates to initiating a perspective known as etic. This type of cognitive process lays the foundation for observa-

[12] A listing of the basic premises of emic and etic viewpoints together with their relevant methodology. See: B. Walczak, Antropolog jako inny. Od pierwszych badań terenowych do wyzwań ponowoczesnej antropologii [The Anthropologist as the Other. From the Annals of Field Research to the Challenges of Post-modern Anthropology], Wydawnictwo Naukowe SCHOLAR, Warszawa 2009, p. 69.

[13] Ibidem, p. 69.

[14] A. Barnard, Antropologia [Anthropology], trans.

P. Szymański, Warszawa 2006, pp. 163-164, cited in:

B. Walczak, op. cit., p. 68. 
tion "from a privileged, exogenous view in the context of a construct transferrable to other cultures." [15]

This second epistomological means of documenting reality is especially important in etic studies, based on observations without and in-house research removed from people and events per se. In this etic context, Fidyk becomes a creative artist who in coming face to face with contrastingly different scenes, forces the audience to question the sense of these events. His extensive knowledge of the various corners of the world provides him with the opportunity to fashion his material accordingly when presenting the nature of the ideology, customs, religions and social relations that prevail in those societies.

Fidyk is not only a well-versed observer of the world who happens to make films; he also has a vast store of knowledge regarding cultural phenomena, which he passes on to the viewer in all of his documentaries. This is very much the case in his film Karnawal. Największe party świata. It is difficult to understand the love Brazilians share for carnival parades, especially if one realises that a majority of those in Rio de Janeiro spend every day in miserable conditions and dire poverty. Their life and carnival parades represent a stark contrast that is difficult to grasp and understand. It is also in this case that Fidyk found a means to illustrate the subject undertaken. The director is able to convincingly share his observations and knowledge with the audience, in the documentary Karnawat. It is thus that Fidyk shows a world of deep social contrasts.

Rio de Janeiro is a city where a huge statue of Jesus is writ bold across its panorama, a religious symbol of pure and true goodness, unfurling its umbrella of love over the city of poverty and bright lights, religion and debauchery, desperation and entertainment. Rio is a city, where as the poem goes:

There are two worlds side by side, heaven and hell.

Both rules corruption, in favelas smugglers of drugs,

criminals aiding beggars, police killing children who have no defence they say for target practice.

In Rio all the state officials shut their windows, they cannot concentrate for the loud shooting in the streets.

Yes, Rio is a city where the rich die of fright, and the poor die of hunger (actress from Fidyk's movie).

These words about Rio reveal the truth about the world in which Brazilians live - in particular those of the lowest social class - which is beset by poverty, homelessness and fear. When the audience of a Fidyk documentary becomes aware of this world where the "biggest party in the world" is staged, they should view these Brazilian "party animals" with curiousity, surprise and awe. But after all, what else can happen when it is so bad, when it appears that it cannot be any worse? There but remains suicide, perhaps revolution? In the meantime the female protagonist on the screen does not mince words:

[15] Ibidem, 69. 
In Rio there will never be a revolution. Revolutions are made only when there is nothing any longer to live for - it's better to die, than to live on living a lifeless life. Rio is worth living for. There are no suicides. Here everyone lives for and waits for the Carnival (actress from Fidyk's movie).

Seeing the world as a spectacle, grand stage or theatre is the world according to the Polish director Fidyk. In this respect, the canonical work of theory on this issue is that of Irving Goffman's Człowiek $w$ teatrze $\dot{z} y c i a$ codziennego. In the introduction to the Polish translation, Jerzy Szacki writes:

I think it is possible to indicate at least two causes of the undoubted success of the author in this work. The first is the constancy and inventiveness in applying the metaphor of theatre harking back to the Ancient World, thanks to which it became transformed into a theoretical construct that is able to convey no doubt even more than Goffman at first was aware of. [16]

Goffman surely was successful - his greatness a result of the fact that "he is able to discover theoretical problems in phenomena that would appear to be the simplest, most obvious - ones not deserving in terms of common sense even a moment of reflection." [17]

One of his reviewers once wrote that he is "a great ethnographer, his tribe is mankind, his centre of interest the direct relationships of daily life, his method of observation the joining of naturalistic field research with diverse works of history, biography, social sciences and belle lettres".[18] It is in a similar vein, it could be said, that Fidyk goes about his work. Andrzej Fidyk, the anthropologist with a camera.

[16] E. Goffman, Człowiek w teatrze życia codziennego [original: The Presentation of Self in Everyday Life, 1956, University of Edinburgh: Edinburgh], Państwowy Instytut Wydawniczy, Warszawa 1981, p. 17. [17] Ibidem, p. 16.

[18] Ibidem, pp. 16-17. Goffman's research methods (if this term is at all appropriate) would make any scholar who had at least some dealings with methodology tear their hair out. First and foremost, he makes use of casual observation on a vast scale, which is not given credence by contemporary sociologists - simply observing those at hand, demanding their reaction in the presence of other people. He also refers to a vast literature that is, after all, apparent in the cornucopia of citations and references, though in a very particular way. In a word, Goffman borrows ideas and examples, and great generalisations that can be found in the works of philosophers, moralists and sociology theoreticians, such as Cooley or Simmel, bits of reality that are to be found everywhere, in literature and reports from sociological research, recollections, guides to good etiquette, travel diaries society chronicles, newspapers and collections of anecdotes. If one had to give an answer to the question of what sources Goffman uses in his work, the answer would have to be: scraps. 